\title{
Obituaries
}

Colin Chalmers Brown, surveyor to two major Antarctic expeditions, died on 25 June 1997. Born in Leatherhead, Surrey, on 28 December 1926, Brown was commissioned in the Royal Engineers immediately after World War II, training in survey. From the army, he transferred in 1947, aged 20, to the Falkland Islands Dependencies Survey, serving for two years at Base E, Marguerite Bay. He took part in several sledging journeys south of the base, and was responsible for surveying the southern end of Marguerite Bay, including King George VI Sound south to Ablation Point. In 1949, when the relief ship was unable to reach Marguerite Bay, Brown found himself an involuntary member of the 'Lost Eleven,' briefly renowned in the British and world press. His fomer colleagues at Base $E$ remember his quiet, pleasant manner, unfailing good humour, professional integrity, and deep enjoyment of all that Antarctica had to offer. Brown was awarded the Polar Medal, and Cape Brown, the northwestern portal of King George VI Sound, is named for him.

Returning to Britain in 1950, Brown assisted Dr Vivian E. Fuchs in setting up the Falkland Islands Dependencies Scientific Bureau in London. Then, after a period of illness, he spent two years studying aeronautical engineering. In 1955, he reverted to survey, joining Hunting Surveys Ltd and returning to Antarctica for two seasons as a surveyor with the Falkland Islands Dependencies Aerial Survey Expedition (FIDASE), 1955-1957. To some degree eclipsed by the more spectacular Commonwealth Trans-Antarctic Expedition, this was a highly competent undertaking led by P.G. Mott, based for two summers at Whaler's Bay, Deception Island, South Shetland Islands. Using a small supply ship and flying two Canso floatplanes and one or two helicopters, FIDASE surveyed the South Shetland Islands and the Antarctic Peninsula area south to the Loubet Coast. As one of a team of four experienced surveyors, Brown ensured good ground control for the aerial photography. His work and personality receive many tributes in Wings over ice, Peter Mott's account of the expedition.

Brown remained with Hunting Surveys for the rest of his working life. Between 1957 and 1965, he was expedition manager to five survey expeditions in Ethiopia, Iran, Libya, Malaya, and Algeria. In 1966, by then an associate of the Royal Institute of Chartered Surveyors, he became Hunting's deputy chief surveyor, returning to Ethiopia and serving in Kenya, Tanzania, Liberia, the Philippines, and Qatar. During the expedition to Liberia in 1969, he contracted cerebral malaria, and, 11 years later, progressive neurological problems that forced his early retirement and increasingly limited his activities.

Despite his debilitating illness, Brown became a member of the entrance board and an external examiner of the
Royal Institute of Chartered Surveyors, and was appointed a Fellow in 1982. With the support of his wife Val and family - Jenny, Simon, and Daniel - he continued for as long as possible his hobbies of sailing, gliding, and painting. He maintained a strong interest in Antarctic affairs, attending, whenever his health allowed, Antarctic Club dinners and lectures at the Royal Geographical Society and the Scott Polar Research Institute.

\section{Bernard Stonehouse}

Air Marshall Sir Christopher 'Cub' Hartley, KCB, $\mathrm{CBE}, \mathrm{DFC}, \mathrm{AFC}$, has died at the age of 85. Hartley took part in two Oxford University Arctic expeditions before World War II. The ony son of the distinguished physical chemist Sir Harold Hartley, he was educated at Eton and Balliol College, Oxford, where his grandfather, A.L. Smith, had been Master and where he was an exhibitioner. He graduated in zoology in 1935, and then spent a year at King's College, Cambridge.

Before going up to Oxford, Hartley took part, as ornithologist, with his friend Edward Shackleton in the Oxford University Expedition to Sarawak, under the leadership of the redoubtable Tom Harrisson. During his long vacation in the following year, he took part - again as ornithologist - in the 18-man expedition to Spitsbergen under the leadership of Alexander Glen. He was a member of the eight-man party based on Billefjorden, an arm of Isfjorden, from where a topographical and geological survey of Dickson Land, and observations in marine biology and ornithology, were made. In 1936, he and Max Dunbar (later professor of oceanography at McGill University) formed a two-man Oxford expedition to spend three summer months in West Greenland. From Christianshåb they headed north by motor boat to the northeast corner of Ata Sund, where they made their base camp. They made a plankton survey of the sound and a hydrographic and biological survey of the crustacean-rich 'feeding zones' for birds off Eqe Gletscher and two other glaciers in the area.

In 1937, Hartley joined the staff at Eton as a biology master, but with the outbreak of war in 1939 he was immediately called up as a pilot in the RAFVR, having trained with the university air squadrons of both Oxford and Cambridge. His distinguished wartime service was spent mainly as night fighter pilot with a Beaufighter Squadron, partly concerned with the best techniques for shooting down the notorious VI 'doodle bugs.'

After the War, Hartley could have rejoined the staff at Eton, but opted instead for a permanent commission in the RAF. He rose steadily in the service, until his final appointment as Controller of Aircraft at the Ministries of Aviation and Technology, which post he held for four 
years, being closely involved in the development of Concorde.

After retirement from the RAF in 1970, Hartley moved into the aerospace industry, becoming a director of the
Westland Helicopter Company, and later the first chairman of the British Hovercraft Corporation. He is survived by two sons of his second marriage.

Geoffrey Hattersley-Smith

\section{In Brief}

CANADA ELECTED TO SCAR. On 27 July 1998, at the twenty-fifth meeting of the Scientific Committee on Antarctic Research (XXV SCAR), held in Concepción, Chile, Canada was formally elected a full member of SCAR.

In preparation for this, Canada had established a national Antarctic committee, named the Canadian Committee for Antarctic Research (CCAR). The first director of CCAR is Professor Warwick F. Vincent of Université Laval. CCAR essentially replaces the Canadian Antarctic Research Program (CARP), which existed for five years under the chairmanship of Professor Peter Suedfeld of the University of British Columbia.

HISTORY IN COLOUR. The Arctic Press has produced a stunning set of reprints of eight nineteenth-century coloured lithographs that were based on the famous sketches made by Lieutenant Samuel Gurney Cresswell during the 1850-54 voyage on HMS Investigator. Cresswell's sketches from this expedition under Robert McClure, which marked the first completion of the Northwest Passage, are noted for their vivid colours. Copies of the original lithographs are virtually unattainable today. For an order form, contact Patrick Walcot, 60 Sunnyfield Road, Sutton Coldfield, West Midlands B73 5RJ, United Kingdom; fax: + 44 (0)121-386-1251.

TERRIS MOORE. In the Polar Profile about the late Terris Moore (Polar Record 34 (189): 149-151 (April 1998)), it was incorrectly stated that Moore was a member of the Mount McKinley expedition on which Allen Carpé lost his life. Moore and Carpé climbed together many times, but not on that occasion. It should be added that, in 1951, Moore made several landings in his Piper Supercub at $3000 \mathrm{~m}$ on Kahiltna Glacier to provide the key support for the first ascent of Mount McKinley by the west buttress, a climb made under the leadership of Bradford Washburn.

(Geoffrey Hattersley-Smith) 